\title{
SELJUK'S MATERIAL CULTURE IN UKRAINE ACCORDING TO THE RESULTS OF HISTORICAL AND ARCHAEOLOGICAL RESEARCH
}

วெá

\section{TARİHSEL VE ARKEOLOJİK ARAŞTIRMA SONUÇLARINA GÖRE UKRAYNA'DA SELÇUKLULARIN MADDI KÜLTÜRÜ}

\author{
Svitlana BILIAIEVA* \\ Anatoliy KARASEVYCH** \\ Sergei KUTSENKO***
}

\begin{abstract}
As a result of massive historical and archaeological investigations of the last decades of the $20^{\text {th }}$ and $21^{\text {st }}$ centuries, numerous samples of the material cultural heritage of the Seljuks were discovered in Ukraine. The researchers identified the stages of its development, main spheres of influence and features of manifestations. The first stage covers the period from the appearance of Oghuz on the territory of the Southern principalities from the middle of the $11^{\text {th }}$ century to the first half of the $13^{\text {th }}$ century. At this time, Seljuk influence can be traced in the applied art and decorative style of monumental architecture of Kyiv Rus. At the next stage - from the second half of the $13^{\text {th }}$ century to the end of the $15^{\text {th }}$ century, the influence of the Seljuks affected a wide range of material culture in the Black Sea region of the Mongol Empire, the Crimean Khanate, the Grand Duchy of Lithuania and Rus. Bright examples of this time are artifacts from the cemetery of Mamay Surok (Zaporizhzhia region), examples of monumental architecture in cities and fortresses of Eastern Podillya, Southern Ukraine and the Crimea (Torhovytsia, Yurkivka, Solkhat). The last discovery of Seljuk architectural style is a stone carving that adorned the wall of the entrance gate of the Tiahyn fortress in the $14^{\text {th }}-16^{\text {th }}$ centuries (Kherson region). From the end of the $15^{\text {th }}$ century to the end of the $18^{\text {th }}$ century Seljuk heritage became a part of the material culture in the Northern Provinces of the Ottoman Empire and was widespread in the monuments of the Northern Black Sea Coast. The material culture of the Seljuks became a kind of cultural bridge that combined the achievements of Eurasia, the civilizations of the Middle Ages and early modernism.

Keywords: Kyiv Rus, the Crimean Khanate, the Ottoman Empire, Turkic-East Slavic contacts, Torks-Oghuzes

\footnotetext{
* Doctor of Historical Sciences, Professor, Department of World History and Teaching Methods in Pavlo Tychyna Uman State Pedagogical University, Ukraine.

ORCID ID: https://orcid.org/0000-0003-3113-7619 • E-mail: svitbil@ukr.net

** Candidate of Philosophical Sciences, Professor, Dean of Faculty of History in Pavlo Tychyna Uman State Pedagogical University.

ORCID ID: https://orcid.org/0000-0002-4261-6386 — E-mail: karasevych@ukr.net

*** Candidate of Historical Sciences, Lecturer, Department of World History and Teaching Methods in Pavlo Tychyna Uman State Pedagogical University.

ORCID ID: https://orcid.org/0000-0002-8020-2141 • E-mail: kutsenka7@gmail.com
} 


\section{$\underline{0 ̈ z}$}

20 ve 21. yüzyılın son on yılları boyunca yapılan büyük ölçekli tarihi ve arkeolojik araştırmaların bir sonucu olarak, Ukrayna topraklarında Selçuklular'ın maddi kültürel mirası dahilinde çok sayıda eser/kalıntı keşfedilmiştir. Bunların gelişim aşamaları, ana etki alanları ve tezahürlerinin özellikleri belirlenmiştir. İlk aşama Oğuzlar'ın 11. yüzyılın ortalarında Güney Rus knezliklerinde ortaya çıkışından itibaren 13. yüzyılın ilk yarısına kadar olan dönemi kapsar. Bu dönem Selçuklu etkisi, Kiev Knezliği anıtsal mimari anıtlarının uygulamalı sanatında ve dekoratif üslubunda izlenebilmektedir. Bir sonraki aşamada, 13. yüzyılın ikinci yarısından itibaren 15. yüzyılın sonuna kadar, Selçuklular'ın etkisi, Moğol İmparatorluğu'nun Karadeniz bölgesinin, Kırım Hanlığı'nın, Litvanya ve Rus Büyük Dükalığı'nın maddi kültürünün geniş alanını etkilemiştir. Bu dönemin parlak örnekleri, Mamai Surka Mezarlığı'ndaki (Zaporojye bölgesi) eserler, Doğu Podillya, Güney Ukrayna ve Kırım (Torgovitsya, Yurkivka, Solhat) şehir ve kalelerinin anıtsal mimarisinin örnekleridir. Selçuklu mimari üslubunun son keşfi, 14-16. yüzyıl Tyahın Kalesi'nin (Herson bölgesi) giriş kapısının duvarını süsleyen bir taş oymadır. 15. yüzyılın sonundan itibaren 18. yüzyılın sonuna kadar Selçuklu mirası, Osmanlı İmparatorluğu'nun kuzey vilayetlerinin maddi kültürünün bir parçası haline gelmiş ve Kuzey Karadeniz kıyısındaki anıtlarda geniş çapta yayılmıştır. Selçuklular'ın maddi kültürü, Avrasya'nın başarılarını, Orta Çağ uygarlıklarını ve erken moderniteyi birbirine bağlayan bir tür kültür köprüsü olarak belirmektedir.

Anahtar Kelimeler: Kiev Knezliği, Kırım Hanlı̆̆l, Osmanlı Devleti, Türk-Doğu Slav ilişkileri, Torklar-Oğuzlar 


\section{Historical Review}

Global migration processes of the I - the beginning of the II millennium, in particular the settlement of the Turkic peoples, led to the formation of a new ethno-cultural situation in the vast Eurasian area. The following main steps of the processes are noted:

- migration of various ethnic communities (non-Slavic origin) from the East to the South-West during the early middle ages, which partially remained in the region in subsequent times and caused the uniqueness of the ethno-cultural space and its material manifestations $\left(5^{\text {th }}-\right.$ mid- $11^{\text {th }}$ centuries $)$;

- waves of nomadic Turkic population of the late early middle ages and high middle ages from the Asian area to Eastern Europe and the Mongol Empire inclusive; formation of the steppe bridge from China to Eastern Europe inclusive; formation of syncretic ethno-cultural space $\left(11^{\text {th }}-14^{\text {th }}\right.$ centuries $)$, creation of the meridian cultural environment between the Baltic Sea and Black Sea.

As D. O. Rasovskyi noted back in 1933, "the history of the Turkic peoples settlement on the territory of neighboring sedentary states, and especially the question of their settlement on the border of these states, has every right to be singled out as a special topic and to be studied throughout the vast space from the Far East to Central Europe along the entire route and collision of the Turks with sedentary cultures." 1

After waves of invasion and creation of the first Turkic states in the second half of the I millennium A.D., in the 10th century a new wave of the Aral Oghuzes poured into the western steppe of the Caspian region due to the objective natural factor - the extremely hard drought that hit the steppe zone. There they had to fight the oghuzes who had been converted to Islam. ${ }^{2}$ At the time when the state of the Great Seljuks was formed on the territory of Turkmenistan, which existed from 1037 to 1194, the Oghuzes-pagans who did not accept Islam and were defeated by the Oghuzes Muslims, moved towards the borderlands of the Rus. O. I. Prytsak believed that the Oghuz migration began after 1043, when they entered the territory of the state of Yabgu of the Oghuz Turkmens to the east of the Volga. ${ }^{3}$ Their vanguard came to the Principality of Pereyaslav in $1054 .{ }^{4}$ Since 1055 , they are known as "Torks" in the old Rus chronicle.

Thus, on the territory of the Rus-Ukraine, we can find formations of Turkic tribes close in ethnic origin to the oghuzes, who created the Seljuk Sultanate. ${ }^{5}$ Both they and those who presented Seljuk culture as a phenomenon of the Eurasian scale had the same ethno-cultural roots and the oldest traditions of the cosmogonic level of the Turkic peoples. In turn, they came from the oldest worlds of the Scythian horizon, which in a

1 Rasovskyi, 2016, 133.

2 Humilev, 1993, 301.

3 Prytsak, 2007, 31-32.

4 Beliaeva, Bubenok, Hundohdyev, Dryha, Mavrina, 2018, 18.

5 Beliaeva, Bubenok, Hundohdyev, Dryha, Mavrina, 2018, 21. 
broad interpretation was also distributed to nomadic tribes of Siberia, Kazakhstan and Central Asia. ${ }^{6}$ The elements and motifs of the ornament embodied in the complex of material culture were included in the cultural heritage of the Turks of various areas of their settlement. Therefore, the concept of "Seljuk culture" has a narrow and broad meaning. In a narrow sense, it is the culture of the Seljuks themselves within their territorial settlement and the corresponding state entities within the chronological and territorial boundaries of their existence. It was formed as a result of the movement of Oghuz tribes to the south west from Central Asia through the Caucasus and Iran towards Byzantium. After defeating the Byzantine army in 1071 it was widely distributed in Anatolia. Extremely important areas of this movement were the regions where the changes caused by the evolution of local states which coincided with the military and political activity of the Seljuks. One of these regions was the Caucasus, whose fate in the $11^{\text {th }}-12^{\text {th }}$ centuries was integral to the Seljuk influence. ${ }^{7}$ At the same time, the state of Kerman Seljukids is being created on the territory of Iran, Afghanistan, Pakistan, and Oman: the Koni Sultanate that existed in 1077-1307. on the lands conquered from the Byzantine Empire. In the $12^{\text {th }}-13^{\text {th }}$ centuries Anatolia was on the rise of architecture and decorative arts. This rise laid the foundations of Seljuk Anatolia, which became a powerful cultural corestone of the Ottoman Empire and affected the development of Eastern Europe. A special place in the construction industry was occupied by large caravanserais, which were used as transshipment points and trading centers of the caravan trade. During the Seljuk period, more than 100 of such buildings were constructed. The cities of Konya, Kayseri and Sivas were centers of craft and trade ${ }^{8}$.

But in a broad sense, it contains both the history of developed centers of Seljuk culture and the historical and political development of Oghuz centers related to the Seljuk in Eastern Europe, and those features that are defined in regions beyond its borders, but will clearly indicate the peculiarities inherent in the Seljuk culture.

Stage One. The Oghuzes in the Rus. (Fig. 1). A specific feature of the process that occurred with the Oghuzes of the north stream is that they found themselves in the conditions of the existing Rus state, adapting to the cultural environment to which they fell. The historical development of the north stream in chronological terms is divided into two periods. The first period covers the time from the appearance of the Oghuzes on the borders of Southern Rus in the middle of the $11^{\text {th }}$ century to the $40 \mathrm{~s}$ of the $13^{\text {th }}$ century. It is marked by various factors. First, it is the historical and political development of the Oghuz tribes in the Rus. The process of emergence and settlement of the Oghuz tribes in Eastern Europe (north stream) reflects the formation of a new ethno-historical and ethnocultural space of their own existence, in contact with the Slavic tribes, the possibility of mutual influence, integration of material culture elements. In concrete historical terms, this process is connected with the activity of the Grand Prince of the Rus Yaroslav the

6 Kuklina, 1985, 188-190.

7 Husein-Zade, 2013, 7.

8 Krymskyi, 1996, 14-20. 
Wise. He gave the Torks, who had gone over to the Rus, the land between the rivers Stugna and Ros on the right bank of the Dnipro. ${ }^{9}$ In the $12^{\text {th }}$ century the Torks became active participants in the events of the history of the Rus. ${ }^{10}$ In Porossia, they created the Union of Black Hoods, which became part of the Rus with the capital city of Torchesk.

Chronicles and archaeological researches indicate the settlement of the Oghuzes on the vast territory of the left bank (Livoberezhzhia) and right bank (Pravoberezhzhia) of the Dnipro within the central principalities of the Rus land: Kyiv, Chernihiv and Pereyaslav, but the real map of the Oghuz distribution requires further clarification. The idea of their material culture is somewhat fragmentary. The localization of the settlement structure of the Oguzes and the study of material culture on the territory of Kyiv Region began in the $19^{\text {th }}$ century (V. V. Khvoiko) and continued in the second half of the $20^{\text {th }}$ early $21^{\text {st }}$ century. (B. O. Rybakov, M. P. Kuchera, L. I. Ivanchenko, A. P. Motsia, A. V. Borysov). The largest settlement of the Oghuzes in the Rus was Torchesk, whose area according to A. V. Borysov's research was 139.33 ha (51.7 ha of the fortified part of the settlement and 87.63 ha of the adjacent settlement). ${ }^{11}$ Its occurrence is usually dated between 1083-84 and 1093, and consequently, the process of city formation dates back to an even earlier time. Taking into account the first mention in the chronicle on the border with the Principality of Pereyaslav in 1055, we are talking about a fairly soon appearance of the city after the arrival of the Torks. Today up to 200 settlement and burial monuments of the Oghuzes of Porossia Region have been identified, and a gradual transition to sedentary forms of existence during the $12^{\text {th }}$ - early $13^{\text {th }}$ centuries. A. V. Borysov attempted to reconstruct the population of Torks within Porossia. It was about 45 thousand, equal to the number of one horde.

The works of V. P. Kovalenko, Y. M. Sytyi are devoted to the localization of the Oghuzes in Chernihiv Region ${ }^{12}$, and the works of A. V. Kolybenko and O. V. Kolybenko in Pereyaslav Region ${ }^{13}$. According to their observations, there is no compact placement of the Torks in Chernihiv Region, and there are also selective indications regarding their settlement in Pereyaslav Region.

The burial monuments of the Oghuzes are studied somewhat better, but also there are certain problems with the allocation of material culture and anthropological materials, particularly with regard to the comparative characteristics with other monuments (S. O. Pletneva, G. O. Fedorov-Davydov, P. P. Tolochko, O. P. Motsia, R. S. Orlov and others) allowed us to attempt to determine the composition and belonging of the actual material complex of the Torks, which has many features in common with other cultures of Turkic origin, in particular the ornamental base of Seljuk culture, with which they are connected

9 Ivanchenko, 2009, 387.

10 Tolochko, 1999, 8.

11 Borysov, 2020, 8.

12 Kovalenko, Sytyi, 2004, . 121-138.

13 O. Kolybenko, O. Kolybenko, 2006, 113-116. 
by common ethnic roots and traditions. This is determined by some features of the clothing inventory of the Torks burial sites, particularly jewelry. Among the mass finds there are temple rings and round-shaped earrings made of silver or bronze wire and an addition in the form of round or rhombic beads, classic pendants-bells and buttons, etc.

Of particular interest are the finds of fragments of silver and gilded jewelry (Fig. 2) in a female burial near the village of Burty in Kaniv Region. ${ }^{14}$ This is a fragment of jewelry that has preserved a zoomorphic image (the back of the body with a high-raised curled tail and two paws), a close analogy to which is on the lampshade of the lamp, in the form of a cage from Konya of the $13^{\text {th }}$ century. ${ }^{15}$ There are several fragments of jewelry with images of birds. Great interest represents an ornament in the form of two parts of a ring with a figure of a bird between them, the pose of which resembles a figure of an eagle with the wings on both sides of the body, turned to the side with the head resting on the support of the ring (Fig.2,10). The iconography of the image reflects the image of a heraldic eagle in the Byzantine style. Analogies of the image are widely known in both Byzantine and Seljuk art, are widely found in the architecture and applied art of the Seljuks, in particular on metal products. Thus, a close image on a copper site, dated between $1114-1144$, a bronze mirror of the mid- $13^{\text {th }}$ century. ${ }^{16}$

One of the most significant archaeological finds is a gilded helmet from a mound near the village of Babichi in Cherkasy region. ${ }^{17}$ The lower part of the helmet is encircled by a classic element of Seljuk applied art: a sprout with two leaves. The upper part is decorated with another ornamental element - a motif of three petals, which is inscribed in a heart-shaped figure (Fig. 3). according to the classification of G. O. Fedorov-Davydov, the helmet belongs to group IV, which dates back to the $12^{\text {th }}-13^{\text {th }}$ centuries. ${ }^{18}$

The development of classical Seljuk culture in Ancient Rus times. As for the influence of the classical Seljuk culture, represented by the developed civilization of Asia Minor, on the territory of Ukrainian lands and Eastern Europe as a whole, it has several contents that differ in time and essence. This allows us to distinguish three stages and several types of innovations.

The beginning of this process (stage one) belongs to the Ancient Rus time and dates back to the end of the $12^{\text {th }}$-first decades of the $13^{\text {th }}$ century, that is, the time that preceded the Mongol-Tatar invasion. It concerns the Eastern Slavic territory and Northern Black Sea Region, including Crimea. During this period, the influence of the Seljuks can be seen in some branches of material culture, decorative elements of monumental architecture, decorations for the elite layer of society in Ancient Rus. The fact is that there

14 Pletneva, 1973,74.

15 Erginsoy, 1988, 210.

16 Erginsoy, 1988, 135-136.

17 Pletneva, 1973, 95.

18 Fedorov-Davydov, 1966, 115. 
are some changes in the decor of Ancient Rus architecture of the $12^{\text {th }}$ - first half of the $13^{\text {th }}$ centuries, in particular in stone carving, teratological style of manuscripts, jewelry, fabrics. They have received different explanations in the scientific literature: Slavic pagan heritage and interpretation of the meaning of the symbolism of individual elements, the influence of Byzantine or Western European art. Nevertheless, the classical features of Romanesque architecture in Byzantium and its decorative elements were supplemented by a powerful layer of Seljuk cultural wealth, in particular the Seljuk Anatolia with innovations in architecture and applied arts. In the XII - first half of the $13^{\text {th }}$ centuries, the Seljuk cultural influence penetrated and spread in the area of the Byzantine cultural circle, in particular in the South of Eastern Europe: the Danube-Dniester Interfluve, the Lower Dnipro, and the Crimea. This can be traced, first of all, to the finds of imported sgraffito ceramics, analogies of which are known from the excavations of the Kubadabad Palace in Beyşehir (1236), the Alaeddin Palace in Konya (1156-1192), etc. A brilliant example of artistic ceramics of the $12^{\text {th }}-13^{\text {th }}$ centuries is the image on a bowl from the excavations of Chersonesos, the Crimea. ${ }^{19}$ It shows a man in a wide robe and trousers, with a hunting net in his hands, posed next to a falcon and a dog. The subject of the painting and the composition of the characters is similar to the paintings of construction ceramics of the second half of the $12^{\text {th }}$ - first half of the $13^{\text {th }}$ century in Seljuk palaces in particular Kubadabad and Konya. ${ }^{20}$ The painting is made in the color scheme typical for glazed tiles of Seljuk palaces — black on a light blue background. Among the glazed sgraffito ceramics that came from Asia Minor to the Crimea and the territory of the East Slavic world in the first half of the $13^{\text {th }}$ century. There are instances, decorative elements of which are similar among the samples of dishes from the Seljuk the Kubadabad Palace in Beyşehir. These are leaf-shaped and ribbon combinations, heraldic figures with a cross, scalloped surroundings, and six-pointed stars. ${ }^{21}$

In metal products of applied art of the $12^{\text {th }}$-first half of the $13^{\text {th }}$ century. bracelets and kolts that are related to the items of clothing of women of the highest circles of Rus society, even taking into account the wide migration of certain motifs that are repeated in many cultures over a large area, there are features characteristic of Eastern art. First, it is the subjects, compositions and decorative style of some bracelets, such as the bracelet from the Kyiv treasure No. 94 found in $1893 .{ }^{22}$ According to V. H. Putsko, the style of images of one of the bracelets is close to the best Constantinople, that is Byzantine samples and, at the same time, has analogies in the decorative motifs of Eastern fabrics. ${ }^{23}$ Gryphons and birds, weaves and trefoils, decorative motifs (weaving, the motif of the braided beast) are more in tune with the motives of the Seljuk Anatolian art than with

19 Ryzhov, 2005, 66.

20 Öney, 1992, 100, 102-103.

21 Öney, 1992, 107-108.

22 Korzukhyna,1954, 116.

23 Putsko, 2007, 107. 
the image elements and style of the Byzantine ornament. ${ }^{24}$ The Kyiv bracelet from the treasure of 1903 is especially close to the Seljuk applied art in terms of themes, images and a decorative design. The leaf of the upper tier of the bracelet shows the motif of the "tree of life" in the middle and two birds on either side of the tree. The remaining images of the upper tier are motifs of a braided animal (leopard) and birds. The lower tier is embraced by weaving and a trefoil folio. Not only the composition, but also the image of the bird scene at the "tree of life" is close to the image on the tile from the Kubadabad Palace in Anatolia (Fig. 4), ${ }^{25}$ as well as the image of bluish-white dishes from the excavations of Samsat of the $12^{\text {th }}-13^{\text {th }}$ centuries. ${ }^{26}$ It is likely that the introduction of certain motifs (the braided beast, the tree of life, weaving, images of trefoils) may have been partly related to the immigration of masters after the events of 1204, when the arrival of the crusaders was a negative and threatening phenomenon among the Seljuk and Byzantine cultural circles.

The second branch of Seljuk interference in the applied art of Rus is the kolts of the Rus elite with the image of sirin. According to the style and certain decorative features kolts are divided into two parts: the first inherits the tradition of the Byzantine Empire, and the second has the sirin image of the Seljuk style, absolutely identical to the image on the tiles of the Sultan's Kubadabad Palace in Konya (Fig. 5) ${ }^{27}$. According to Byzantine ideas, sirins are symbols of death. Therefore, their images were not widely distributed in Byzantium itself. ${ }^{28}$ However, the sirins of Persian art, the sirins of Seljuk palaces, associated with the mentality of the East, Transcaucasia were considered amulets. According to L. Avsar, the combination of both human and animal beings was supposed to protect representatives of a high social level from evil spirits and various insidious actions. ${ }^{29}$ As it is known, sirin has its roots in the most ancient pagan samples, which have common roots, embodied in the goddesses of fertility of the peoples of Eurasia. This pagan phase is the only ethnic basis of the peoples of Turkic origin, the genetic background of cosmogonic ideas. One of the main elements is the cult of the goddess Umai, which is characteristic of the Turkic peoples of the Eurasian space. ${ }^{30}$ She was the patroness of the Turkic peoples, the goddess of fertility, the Lybyd - bird, who created the earth, got a lump of earth from the bottom of the world ocean, from which the mountains, plants and animals grew. It was she who laid the egg that hatched this world. A similar legend of the creation of the world, but already a duck, is characteristic of the VolgaBulgarian and Ugro-Finnish epics. In various forms of art in the Rus, the mentioned plot of the cosmogonic legend can also be found.

24 Makarova, 2000, 125.

25 Öney, 1992, 97.

26 Bulut, 2000, 37.

27 Arık, Rüçhan ve Arık, Oluş 2007, 312.

28 Ryzhov, 2005, 65.

29 Avșar, 2012, 2.

30 Avșar, 2012, 3. 
The symbol of Umay was a trefoil, which was part of the jewelry of Turkic women. In a parallel dimension, the cult of fertility is embodied in the goddess Makosh of the ancient Slavs. As it is known, the latter is almost always found in wells along with the mermaids, the image of which is transmitted in images of birds - sirins in old Rus medieval art. ${ }^{31}$ Therefore, the image of sirin on the kolts of women of the Rus social elite,particularly its capital Kyiv, was in full agreement with the symbol of the amulet, cosmogonic traditions and ideas that were preserved in the Ancient Rus era. ${ }^{32}$

Certain parallels can be seen in the storylines of Seljuk, Byzantine, Western European art and the Rus. In Ancient Rus applied art, subjects with images of lions, leopards and dragons became widespread. It should also be noted that the common idea of the "braided" beast and the griffin, which are found in ancient Rus, Western European and Seljuk art. However, the image of the "braided" beast has peculiar differences in the iconography of Western and Eastern images. The complex weaving of capitals with paired animals, images of trefoils combined with weaving, combinations of palmette and weaving have stylistic touches with various art schools and certain parallels in Seljuk stone architecture. The iconography and list of elements (birds, leopards, dragons, weaves) have parallels in the plots and ornamental details of the white stone carvings of some monumental structures of the Rus, in particular the capitals of the $12^{\text {th }}$ century Borisoglibsky Cathedral in Chernihiv.

Manifestations of new features of the planar style of decorative art are noted in the white stone carving already outside of Southern Rus in the first half of the $13^{\text {th }}$ century, as it is recorded in the white stone carving of the low relief of St. George's Cathedral (1236) of Yuriev-Polsky. Here you can fully see the reflection of the plot of the world creation legend by a duck. The composition is extremely rich in many elements: the image of two birds with a lump in their beak, located on either side of the "tree of life" in the medallion, symmetrically arranged images of other birds, probably peacocks, lions, as well as trefoils, sprouts, leaves, etc. ${ }^{33}$

The evidence of direct contacts between Byzantium, Seljuks and Southern Rus in the first half of the $13^{\text {th }}$ century is the materials of a unique complex in Kyiv, found by G. Y. Ivakin during the excavations of the estate of a rich Kyivan in the tract Gonchary and Kozhumjaky on Podil in 1987-1989. ${ }^{34}$ Among a large complex of various finds artifacts of the Byzantine and Seljuk circle were found. The fragments of a bowl made of thin opaque glass of milky color, decorated with gold painting and red enamel were found. The lower tier of the bowl uses motifs of the "tree of life" and birds near it, as well as a medallion with crosses in the middle. In addition, other fragments of Byzantine colored glass were found on the estate, which together with other materials dates from the

31 Rybakov, 1981, 488.

32 Rybakov, 1987, 122.

33 Rybakov, 1988, 589.

34 Ivakin, 1993, 73-76. 
end of the $12^{\text {th }}$-beginning of the $13^{\text {th }}$ century. By analogy, such a bowl could come from Corinth or the Syrian possessions of the Byzantine Empire. According to G. Y. Ivakin, the owner of the estate could be connected with the Asia Minor trade and was wealthy enough to purchase a very expensive vase. ${ }^{35}$ Essential finds from the estate complex, according to G. Y. Ivakin, are two copper Seljuk coins of Rum - Sultan Suleiman II (1200-1203) and Sultan Kaykaus I (1210 - 1219). ${ }^{36}$ This is the first discovery of Seljuk coins on the territory of Kyivan Rus. They could get to Kyiv as a result of trade operations through the Crimean cities (Chersonesos, Sudak), as well as through direct contacts with the Seljuks in the first half of the $13^{\text {th }}$ century. G. Y. Ivakin does not exclude the possibility that they could get to Kyiv "later, in the middle of the $13^{\text {th }}$ century together with the Mongol troops or Rus detachments that Batu used during the wars in Transcaucasia and the Middle East. ${ }^{37}$ The coins of the Seljuk Empire are found on the territory of the Crimea, in particular in Chersonesos, as isolated finds and in treasures. On the eve of the Mongol invasion, Seljuk geometric ornamentation gradually entered the art of the Crimea. ${ }^{38}$ Thus, on the territory of Ukraine and Eastern Europe as a whole, in the $12^{\text {th }}$ - first half of the $13^{\text {th }}$ centuries, the phenomenon of cultural interference of the Seljuk culture in the era of Kyivan Rus was observed. In fact, this is the first stage of influence of Seljuk culture and its traditions on the territory of Eastern Europe.

The second stage of Seljuk influence in Eastern Europe covers the time of the middle of the $13^{\text {th }}$ century-the second half of the $15^{\text {th }}$ century. Its beginning coincides with the arrival of the Mongol-Tatars, covers the time of the Golden Horde and the Crimean khanate, up to the Ottoman expansion in the last quarter of the $15^{\text {th }}$ century. Further innovations related to the penetration of syncretic culture of the Golden Horde period on a large territory from Western Podillya to the Crimea. This period covers several aspects of the society life, in particular the creation of the infrastructure necessary for the existence and functioning of an Islamic society. Powerful changes are taking place in urban planning, where mosques, madrassas, palaces and mausoleums are being built. The builders from Anatolia offerred the ornamental style in the cities of the Golden Horde of the Northern Black Sea Region. Their influence became stronger and more extensive, they represented monumental architecture and applied art. It reflects the next stage in the development of Seljuk culture, enriched with elements of Islamic traditions. Classical works of this period are found in the Crimea, such as the Uzbek Mosque (1314) and the madrassa (1332-1333) in Solkhat (Old Crimea).

In addition, there are ruins of architectural monuments with Seljuk influences on the Lower Dniester, Lower Dnipro and Eastern Podillya on the border of steppe and forest-steppe zones. In the Lower Transnistria, the influence of the Seljuk style, which probably could have been with the participation of Seljuk masons, was noted in the

\footnotetext{
35 Ivakin, 1996, 192-194.

36 Ivakin, 1996, 196-197.

37 Ivakin, 1996, 198.

38 Akchurina-Muftiieva, 2008, 49.
} 
Bilgorod-Dniester (Akkerman) fortress. This applies to the decoration of the internal buildings of the citadel in the garrison courtyard and some stone structures found in the civil courtyard of the fortress. First of all, these are four fragments of window and door frames decorated with the same type of ornament in the form of an intertwined harness (Fig. 6). In the middle part of the field of the first fragment found near the north wall of the citadel, there are convex circles and a stylized floral ornament resembling a palmetto. Weaving of the second fragment armholes are decorated only with convex circles, on the third there is a small lily flower between symmetrical leaves. At the same time, the lily resembles a simplified palmetto. In the fourth fragment, the jute rests against the original rosette, which has a six-pointed star in the center. All these elements are known on various monuments of Moldova, Wallachia, the Crimea and are widely used in the architecture of Transcaucasia, the Crimea and Asia Minor. ${ }^{39}$ Other architectural monuments include remnants of Seljuk influence on the Lower Dnipro and Eastern Podillya.

During the investigation of the Mosque-Grave settlement in the Lower Dnipro Region (Yurkivka village, Zaporizhzhia Region), the capital of the mosque column made of carved limestone was found, the floral motif of which has Seljuk roots (Fig. 7). The style and decorative elements are similar to the Crimean samples, in particular the columns of the portal of the mosque of Khan Uzbek of the first half of the $14^{\text {th }}$ century. ${ }^{40}$

At the Tyagin fortress, architectural details with Seljuk motifs were found during the research of V. Hoshkevych (1914) $)^{41}$. In 2020 we opened a tower decorated with architectural details with Seljuk-style decor (Fig. 8). On Eastern Podillya during the excavation of the Golden Horde complex near the village of Torhovytsia the architectural details of the monumental structure, ornamented with a palmetto, stylized rosette and a hexagonal star were found ${ }^{42}$ (Fig. 9).

However, it should be noted that the specifics of the spread of Seljuk influences in the architecture of Eastern Europe of the $14^{\text {th }}-15^{\text {th }}$ centuries is the fact that it finds its brilliant manifestations not only in the South, especially in the Crimea. A special place belongs to the architectural ornamentation of the cathedrals of the Moscow Principality of the $14^{\text {th }}-15^{\text {th }}$ centuries, which was created on the basis of familiarization with the experience of Seljuk architecture. ${ }^{43}$ At the same time, as stated by L. O. Beliaiev, the path of motives from the interior of Anatolia to the southern coast of the Black Sea in the Crimea is traced. But the rest of the route passed through the territory of Ukrainian lands, in the South of which we have already noted the presence of monumental architecture with Seljuk design. In part, the path can be traced to the presence of Seljuk architectural monuments in the direction of the North-East of Yurkivka (Zaporizhzhia Region), where, as we noted, there is an analog of Solkhat monuments (Crimea) in the direction of Eastern

39 Shlapak, 2001, 158-162.

40 Saienko, Dziuba, 2006, 287.

41 Hoshkevych, 1914, 48.

42 Bokyi, Kozyr, Pozyvai, 2007, 417-418.

43 Beliaiev, 2016, 22. 
Podillya to Torhovytsia, where there are also details of a monumental structure with Seljuk features. As for the next part of the path, further search and stydies are needed.

The Seljuk culture left a bright and noticeable influence in the syncretic culture of the Golden Horde. This is quite fundamentally and convincingly evident in the artifacts of the large ground burial of Mamai-Surka in the Lower Dnieper Region. Numerous ornaments found in the tombs show the "leaf with a rhombus" motif, stylized lion heads on a bracelet, a serpentine earring, and other details of the Seljuk style ${ }^{44}$ (Fig. 10). Earrings and other artifacts with the image of a snake, similar to the image of a snake-dragon in Seljuk art, were also found in Kyiv, Zinkov (Poltava Region), Bilhorod-Dnstrovskyi (Odessa Region). Among the metal artefacts of the Golden Horde period from the latter is also an image of a six-pointed star on a bronze buckle (Fig. 11,1), a lead ring - seal, on a silver ring with a complex image of a bird, a six-pointed star and a crescent (Fig. 11,2). Various decorative Seljuk motifs are found on the sgraffito dishes of many monuments of the Northern Black Sea Region and the Crimea, in particular in local production centers. As for Bilhorod, the masters used a large number of ornamental elements with typical Seljuk motifs. A very common motif of Bilhorod ceramic sgraffito is the interweaving of wide strips of ribbons forming various shapes. The sign of the six-pointed star, which was also used by local craftsmen, was supplemented with various decorative elements. Some specimens of the ware is decorated with geometric lines and elements of pomegranate. However, the trefoil motif was not widespread in Bilhorod as it was, for example, in Chersonesos in the Crimea, Similar motifs are found on the ceramics of one of the largest cities of the Golden Horde in Velyki Kuchuhury (Zaporizhizha Region) and on the territory of one of the largest Golden Horde cities in Tiahynka village (Kherson Region). ${ }^{45}$

\section{Conclusions}

Thus, the Seljuk culture, which embodied the best features of the Turkic art of Central Asia, the Middle East, the Caucasus and the Byzantine culture, became the creative basis of the Seljuk state's own style with its many innovations and powerful potential, which contributed to its spread far beyond the chronological framework of the Seljuk state. One of the ways of continuity was the inclusion of the Seljuk artistic heritage in the culture of the Ottoman Empire, which determined the third period of Seljuk cultural influences, when classical elements of Seljuk culture were organically incorporated into the ornamental motifs of Ottoman Turkey. The "Golden Fund" of ornamental Seljuk motifs become the heritage of the early Ottoman culture, being present on various types of artifacts that were widely distributed in the vast Ukrainian lands of the Ottoman Empire. Seljuk culture appeared as a kind of bridge that connected the cultural achievements of Eurasia, medieval and early modern civilizations, an organic part of the history and culture of Ukraine ${ }^{46}$.

44 Yelnykov, 2001, 206.

45 Kravchenko, 1986,73.

46 Beliaieva, Hulenko, Fialko, Yevliev, Hrabovska, Manihda, 2018, 72. 


\section{BIBLIOGRAPHY}

Akchurina-Muftiieva, N. M. (2008), Dekoratyvno-prykladne mystetstvo krymskykh tatar XV - persha polovyna XX s.: (Etapy rozvytku, typolohiia, stylistyka, khudozhni osoblyvosti): monohrafiia / N.M. Akchurina-Muftiieva; [Vidp. vyssh. ucheb. zaved. «Krymsk. inzh.-ped. un-t »; In-t yskusstvovedenyia, folklorystyky i etnolohii im. M. Rylskoho NAN Ukr. ; otv. za vyp. N.R. Karamanov]. Simferopol: Simferopol. hor. pidkazka., 392.: il., Vk1. 1. 32 (il).

Arık, R. \& Arık, O. (2007), Anadolu Toprağının Hazinesi Çini Selçuklu Ve Beylikler Çağı Çinileri. İstanbul: Kale Grubu Kültür Yayınları.

Avșar, L. (2012), Kubadabad Çinilerindeki Hapri-Siren Figürünün İzini Sürerken. Akademik Bakiș Dergisi. 31, 1- 21.

Beliaeva, S. - Bubenok, O. - Hundohdyev, O. - Dryha, Y. - Mavryna, O. (2018) Ohuzy na rubezhakh Yuzhnoi Rusy / Ynstytut vostokovedenyia ym. A. E. Krymskoho NAN Ukrainy. K, 223.

Beliaiev, L.A. (2016), Islamskyi Skhid i formuvannia materialnoi kultury Moskovskoi Rusi: o metodychnykh pidkhodakh do otsinky, Povolzka arkheolohiia. № 2, 18-43.

Bokyi, N.M., Kozyr, I.A., Pozyvai, T.D. (2007), Arkheolohichni doslidzhennia zolotoordynnykh pamiatok v baseini Syniukhy, Nove doslidzhennia pamiatok kozatskoi doby v Ukraini. 414-423.

Borysov, A.V. (2020), Davnoruske Porosiia. Systema zaselennia: avtoreferat dysertatsii na zdobutti naukovoho stupenu kandydatury istorychnykh nauk: spets.07.00.04 «Arkheolohiia», NAN Ukrainy, In-t arkheolohii. K., 16.

Bulut, L. (2000), Samsat Ortaçağ Seramikleri (luster ve siraltilar).Izmir: Ege Üniversitesi.

Erginsoy, U. (1988), Maden sanati. Anadolu Selcuklu mimari suslemesi ve el sanatlari. Arkhitekturnoe oformlenie i prikladnoe iskusstvo v seldzhukskoi Anatolii. Izdeliia iz metalla. Ankara: T. I. Bankasi Kultur Yayinlari, 2-e izd. 236.

Fedorov-Davydov, H.A. (1966), Kochevnyky Skhidnoi Yevropy pid vladoiu zolotoordynskykh khaniv. Arkheolohichni pam'iatnyky. M .: 276.

Humilev, L.N. (1993v), Drevnia Rus i Velyka skhodynka. M .: Mys1, 336.

Husein-Zade, R.A. (2013), Seldzhukska epokha istorii Kavkaza. Moskva, 184.

Ivakin, H. Yu. (1996), Istorychnyi rozvytok Kyieva XIII - seredynnyi` XVI st. K., 272.

Ivanchenko, L. Y. (2009), "Bratia” tiurkskykh seldzhukov, prozhyvaiushchye na terrytoryy reky Ros. Literature and culture of the Seljuk epoch. Ashgabat, 389. 
Kolybenko, O., Kolybenko, O. (2006), "Svoi pohany" Pereiaslavshchyny (do problemy lokalizatsii mists poselen pereiaslavskykh torkiv). Slovianski obrii. Kyiv, 113-116.

Korzukhyna, H.F. (1954), Russkye klady IX-XIII vv. M .: Izdatelstvo Akademyia nauk RSR, 226.

Kovalenko, V. P., Sytyi Yu. M. "Svoi pohany" Chernihivskykh kniaziv. Starodavnii. Iskorosten i slovianski hrady VIII-Kh st. - K., 2004. - 121-138.

Kravchenko, A.A. (1986), Srednevekovyi Belhorod na Dnestre (konets XIII-XIV v.). AN URSR, Odes. arkheol. muzei. K: Nauk. dumka, 124.

Krymskyi, A. (1996), Istoriia Turechchyny:: zvidky pochalasia Osmanska derzhava, yak vona zrostala i rozvyvalasia i yak dosiahla apoheiu vnaslidok slavy y mozhlyvosti, Kyiv, 287.

Kuklina, I. V. (1985), Etnoheohrafiia Skifii za antychnym dzherelom. L.: Nauka, 205.

Letopis muzeia za 1914 hod (1916), Vyp. 6. Sost. Hoshkevych, V. Y., Kherson: Izd. Hor. Upr., 48.

Makarova, T.I. (2000), Styleobrazovanye v ornamente Drevnei Rusy. Arkheolohyia vostochnoevropeiskoi lesostepi. Vyp. 14: Evraziiskaia step i lesostep v epokhu ranneho srednevekovia. Voronezh, 123-129.

Na rozi dvokh svitiv. Istorychna spadshchyna Ukrainy ta Lytvy na terytorii Khersonskoi oblasti. Monohrafiia. Kolektyv avtoriv: Beliaieva S., Hulenko K., Fialko O., Yevliev M., Hrabovska O., Manihda O. ta in - Kyiv-Kherson, 72.

Öney, G. (1992), Anadolu Selçuklu Mimari Süslemesi ve El Sanatları. Architectural Decoration and Minor Arts in Seljuk Anatolia. Ankara: Türkiye İş Bankası Kültür Yayınları, 291.

Pletneva, S.A. (1973), Drevnosti Chernykh Klobukov. SAI. Vyp. E1-19. Moscow, 96.

Prytsak, O. (2007), Koly i kym bulo napysano «Slovo o polku Ihorevim». K.: Oberehy, 360.

Putsko, V.H. (2007), Kyivski sribni braslety- naruchni i teratolohichna knyzhna ornamentyka. Yuvelirne mystetstvo - pohliad kriz viki: muzeini chytannia: materialy naukovoi konferentsii 11-13 hrudnia 2006 r., Kyiv, 102-113.

Rasovskyi, D. (2016), polovtsi, torky, pechenihy, berendei. M .: Lomonosov, 200.

Rybakov, B.A. (1981), Yazytstvo drevnykh slovian. M .: Nauka, 607.

Rybakov, B.A. (1987), Yazytstvo Drevnii Rusi. M .: Nauka, 784.

Rybakov, B.A. (1988), Yazytstvo Drevnii Rusi. M .: Nauka, 784. 
Ryzhov, S.H. (2005), Khudozhestvennaia keramika XII-XIII vv. yz Khersonesa. Polyvnaia keramika Sredizemnomoria i Prychernomoria X-XVIII vv. Kyiv, «Stylos», 62-70.

Saienko, V. M., Dziuba S. H. (2006), Znakhidka kapiteli kolony chasiv Zolotoi Ordy v Nyzhnomu Podniprovi. Prychornomore, Krym, Rus v istorii i kulture: Materialy III Sudakskoi mezhdunar. nauch. konf. Kyiv - Sudak: Akadem. periodyka,. T. II. 284-289.

Shlapak, M. (2001), Belhorod-Dnestrovskaia krepost. Issledovanie srednevekovoho oboronnoho zodchestvao. Kyshynev: Izdatelstvo ARK, s. 237.

Tolochko, P. (1999), Kochevyie narody stepei i Kyivskaia Rus. Abrys, Kyiv, 198.

Yelnykov, M. V. (2001), Serednovekovyi mohylnyk Mamai-Surka (za materialamy doslidzhen 1989-1992 rr.). Otv. chervonyi. H. N. Toshcheva. Zaporizhzhia: ZGhU., T. I. 275. 


\section{List of Illustrations}

Fig. 1. Oghuz tribes in Southern Rus in 11th-13th centuries.

Fig. 2. Women's jewelry from the tomb of Burty village.

Fig. 3. Helmet from a tork's burial, Babichy village.

Fig. 4. Storyline on the bracelet from Kyiv and on the tiles from Kubadabad.

Fig. 5. Sirins on ancient earrings and the images on the tiles from Kubadabad.

Fig. 6. Design of the openings in Seljuk style, Bilhorod-Dnistrovskyi fortress.

Fig. 7. Capital of a monumental building, Yurkivka village.

Fig. 8. Architectural details, Torhovytsia village.

Fig. 9. Architectural details, tower of Tiahin fortress.

Fig. 10. Jewelry in Seljuk style, gravedigger of Mamay-Surka.

Fig. 11. 1.- buckle with image of hexagonal star; 2.-ring with image of bird and hexagonal star. Bilhorod-Dnistrovskyi, fortress. 


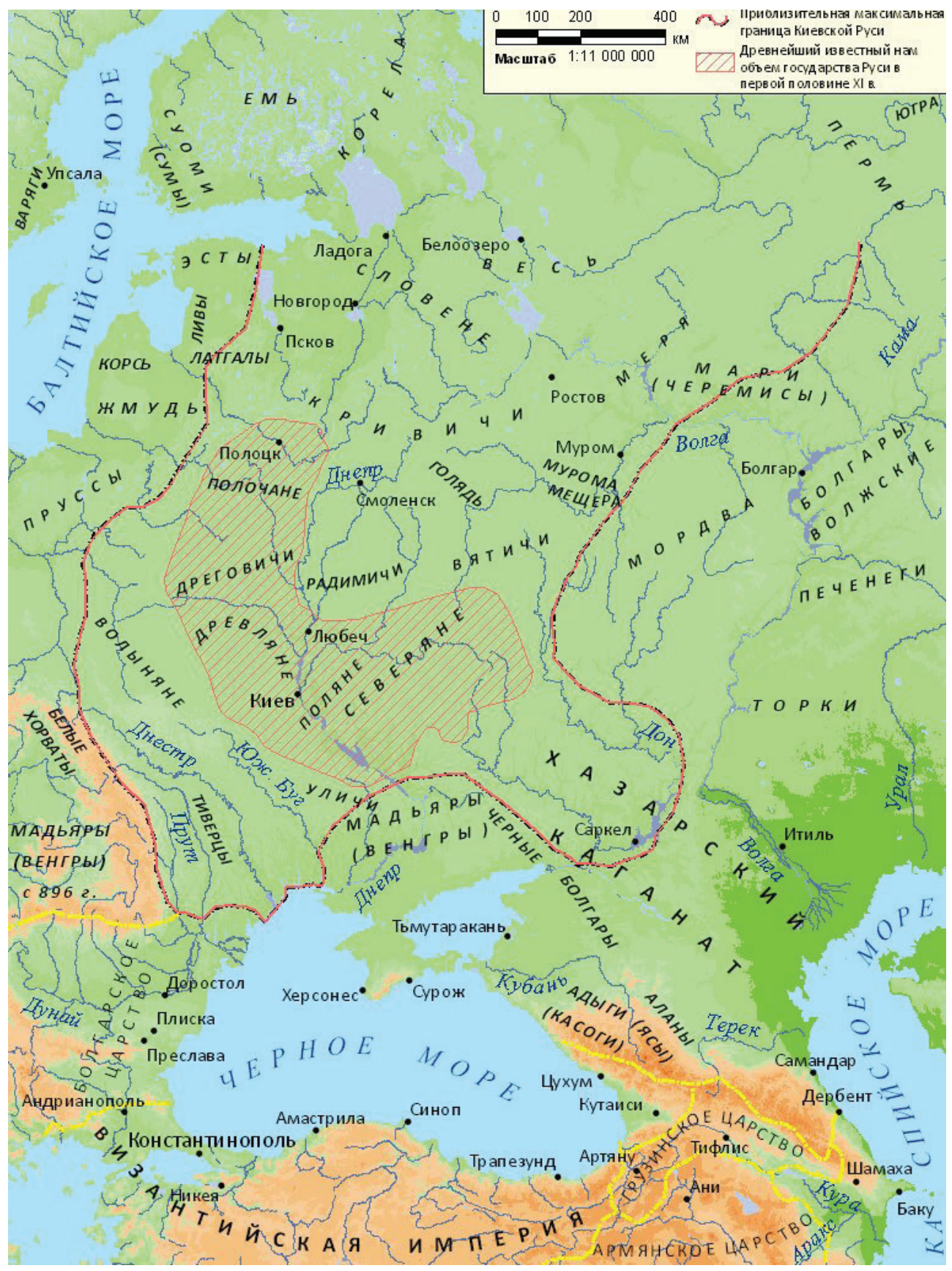

Fig. 1 


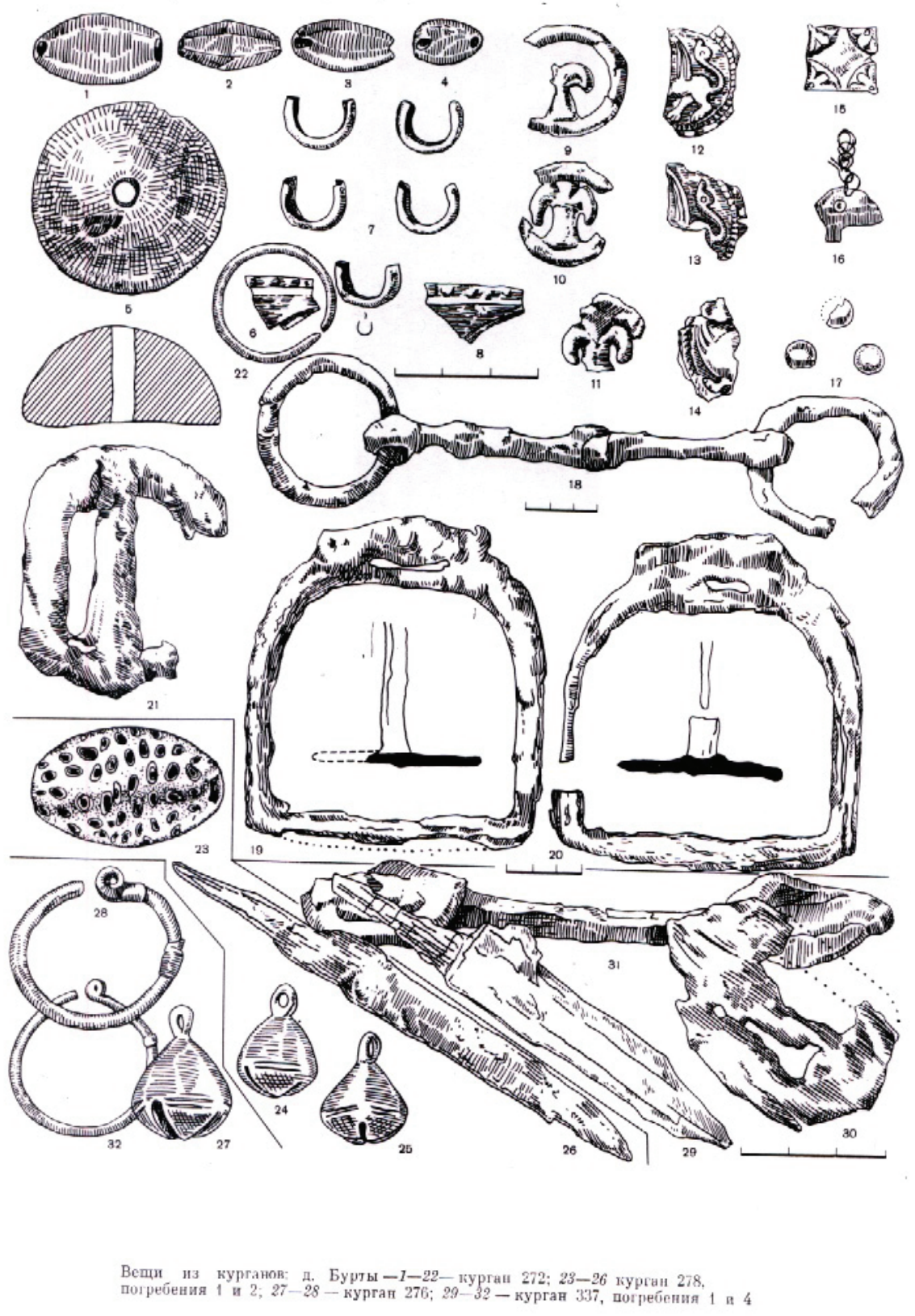

Fig 2 


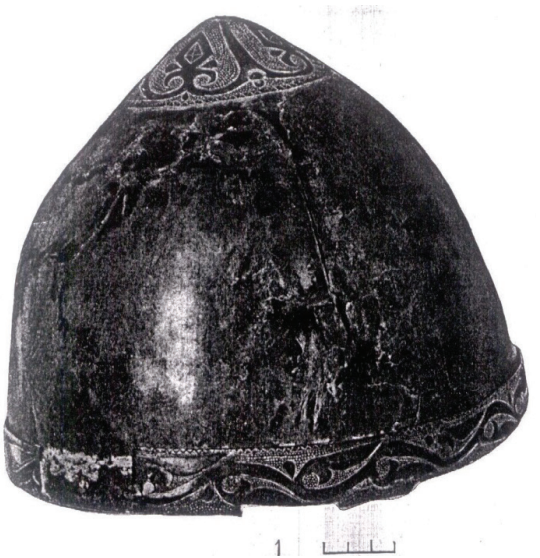

Fig 3
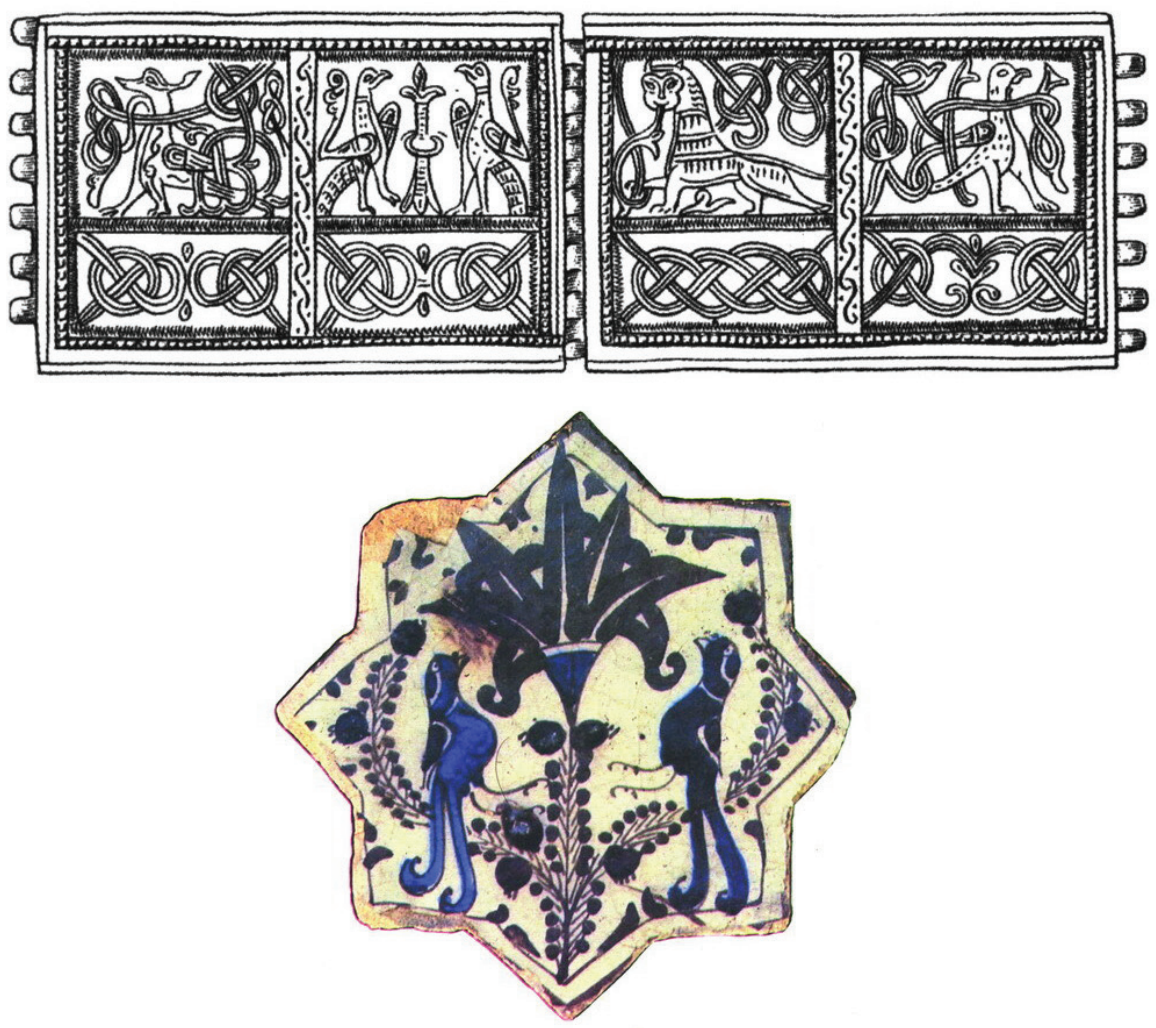

Fig 4 

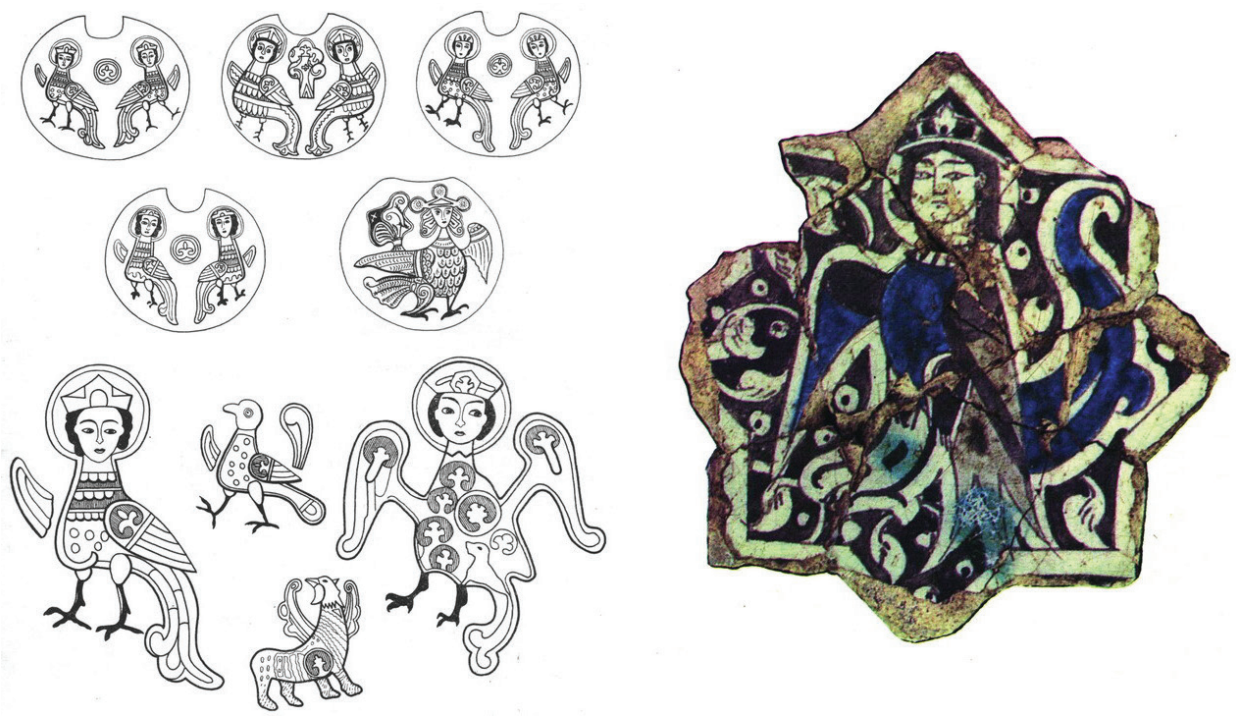

Fig 5
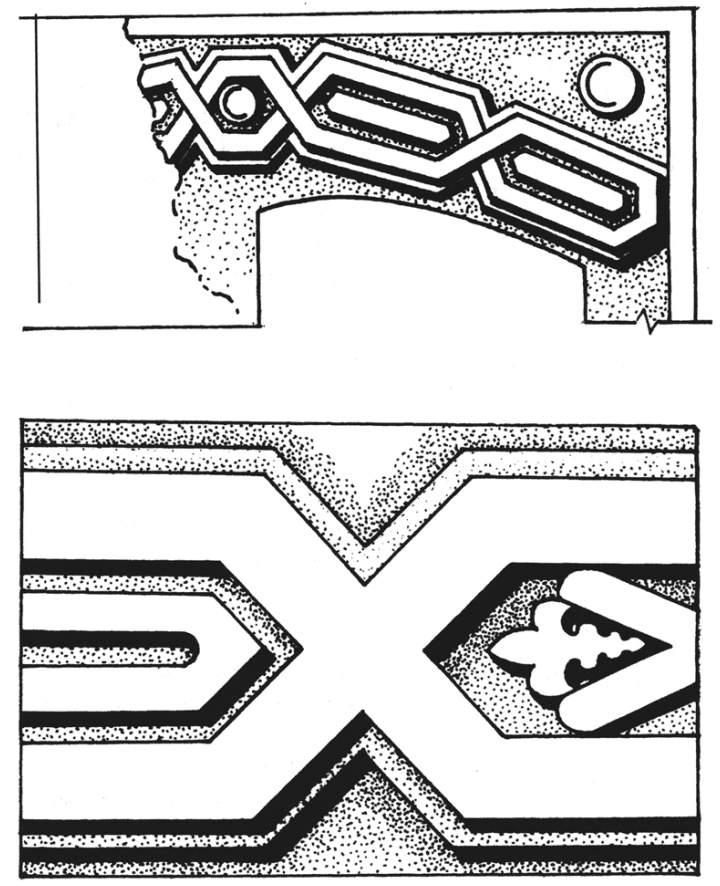

Fig 6 

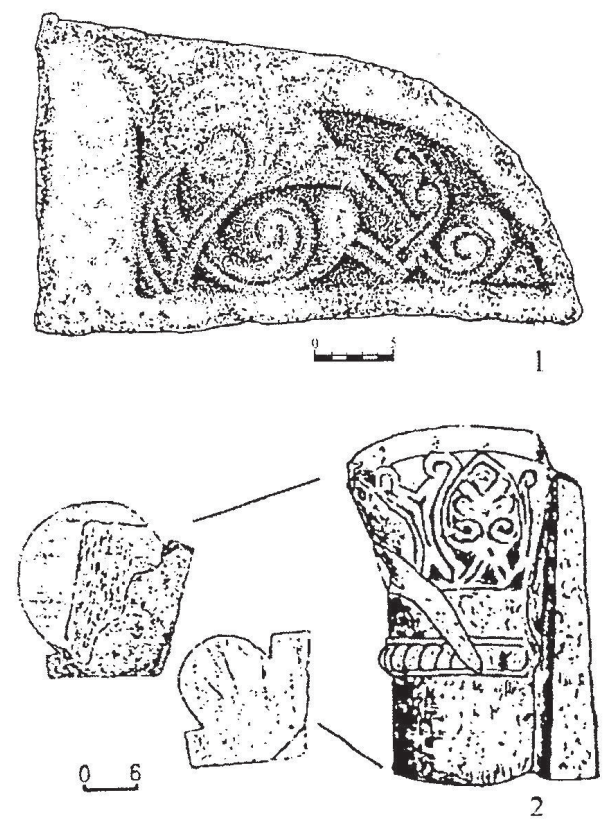

Fig 7
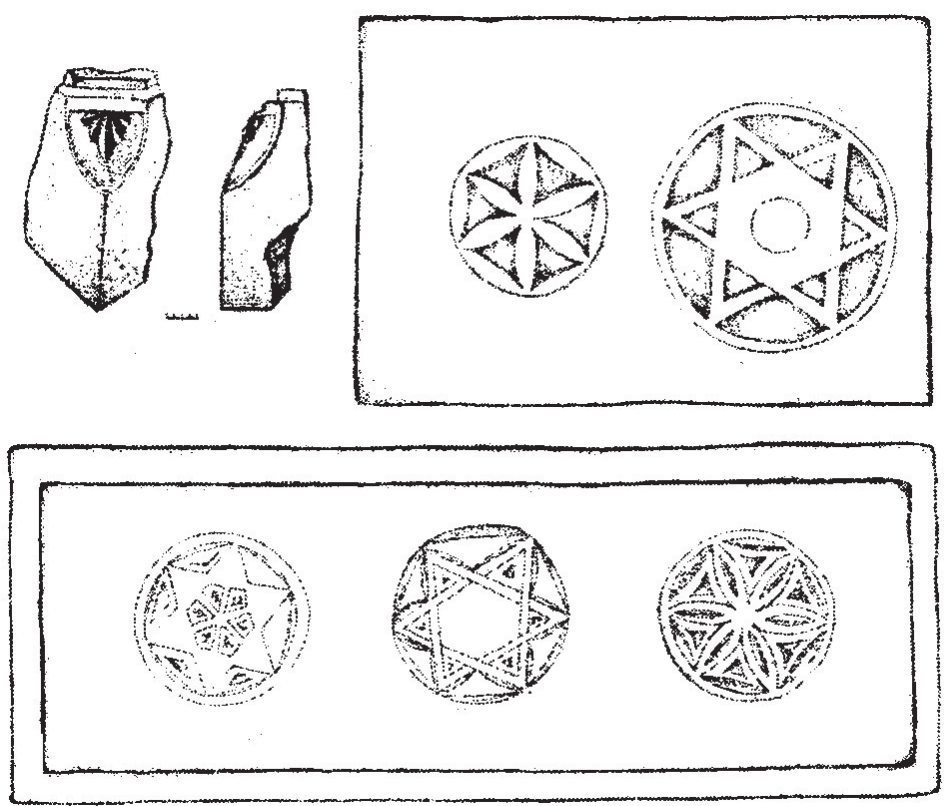

Fig 8 


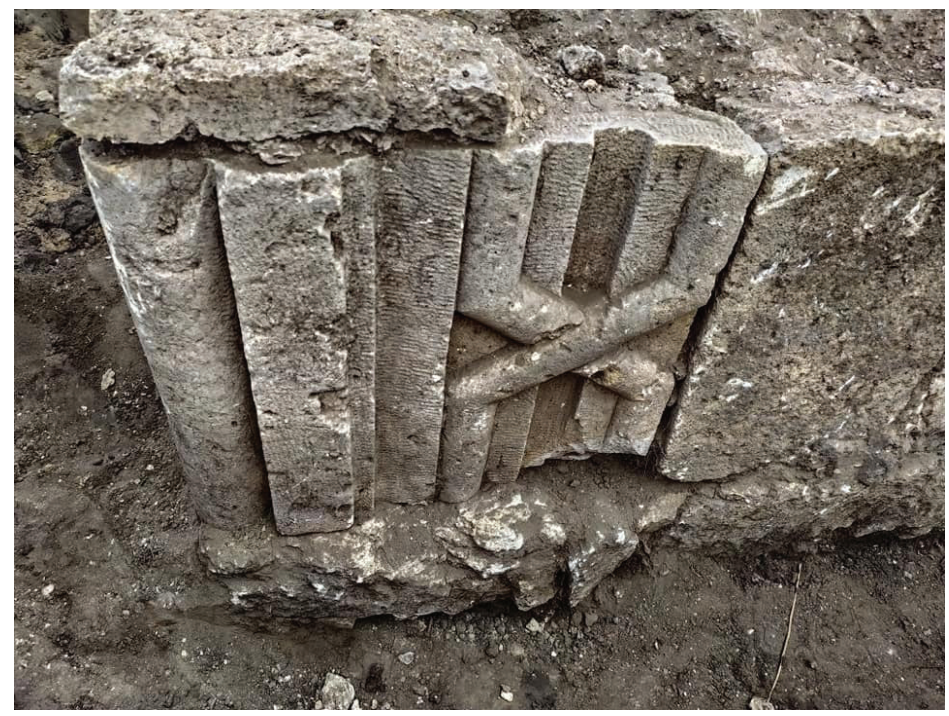

Fig 9
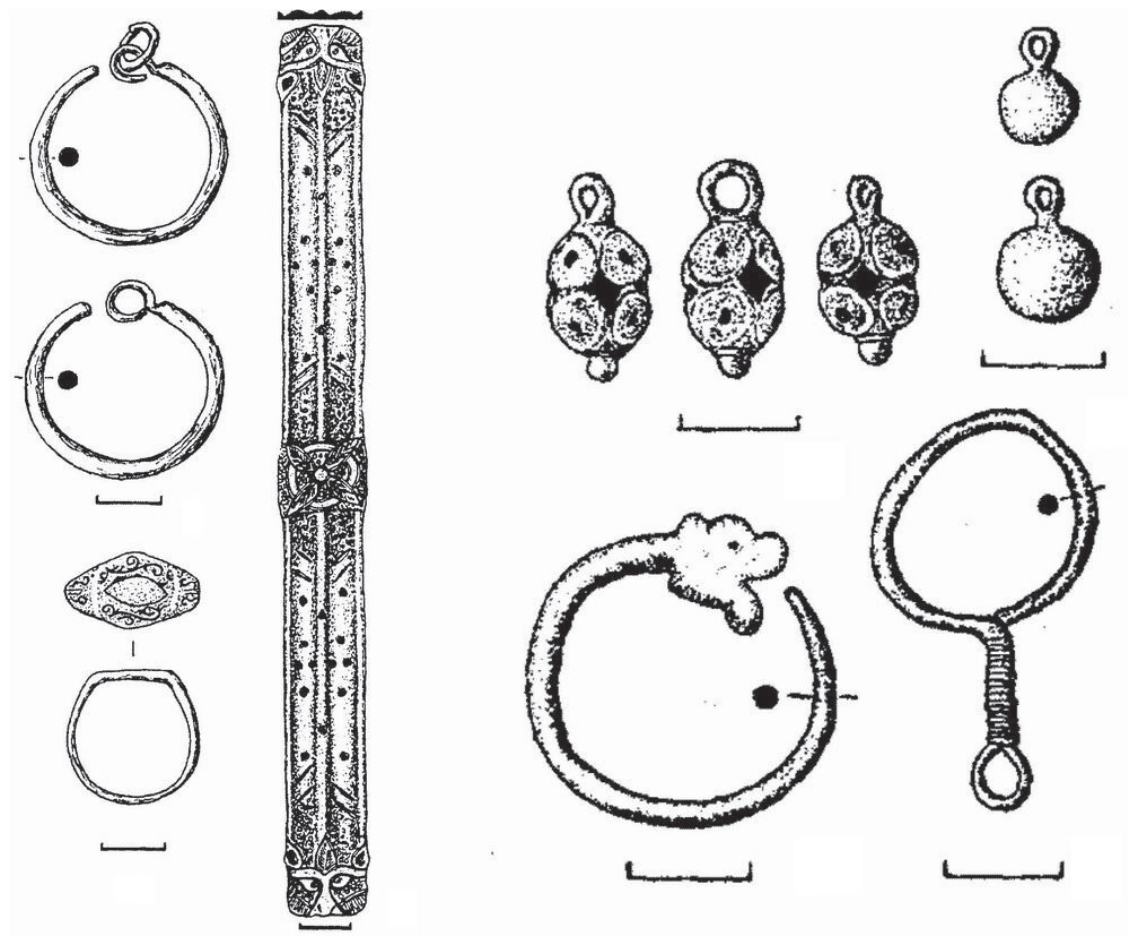

Fig 10 


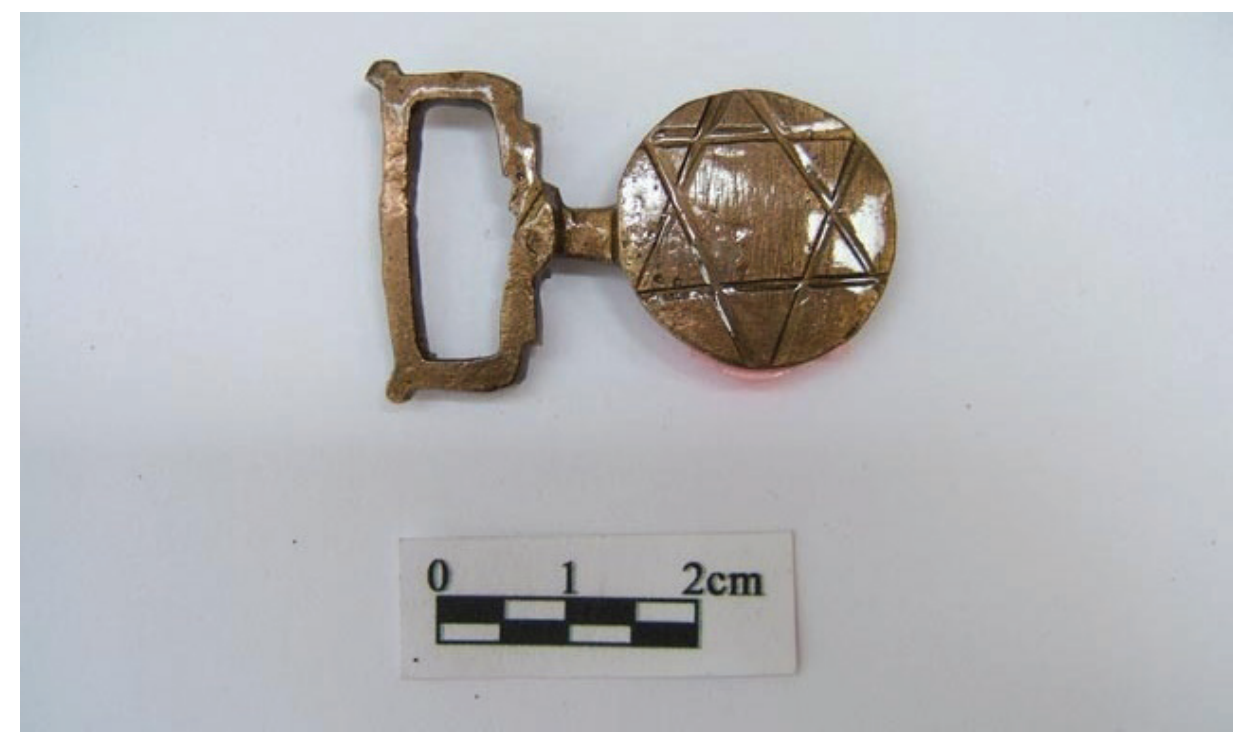

Fig 11.1

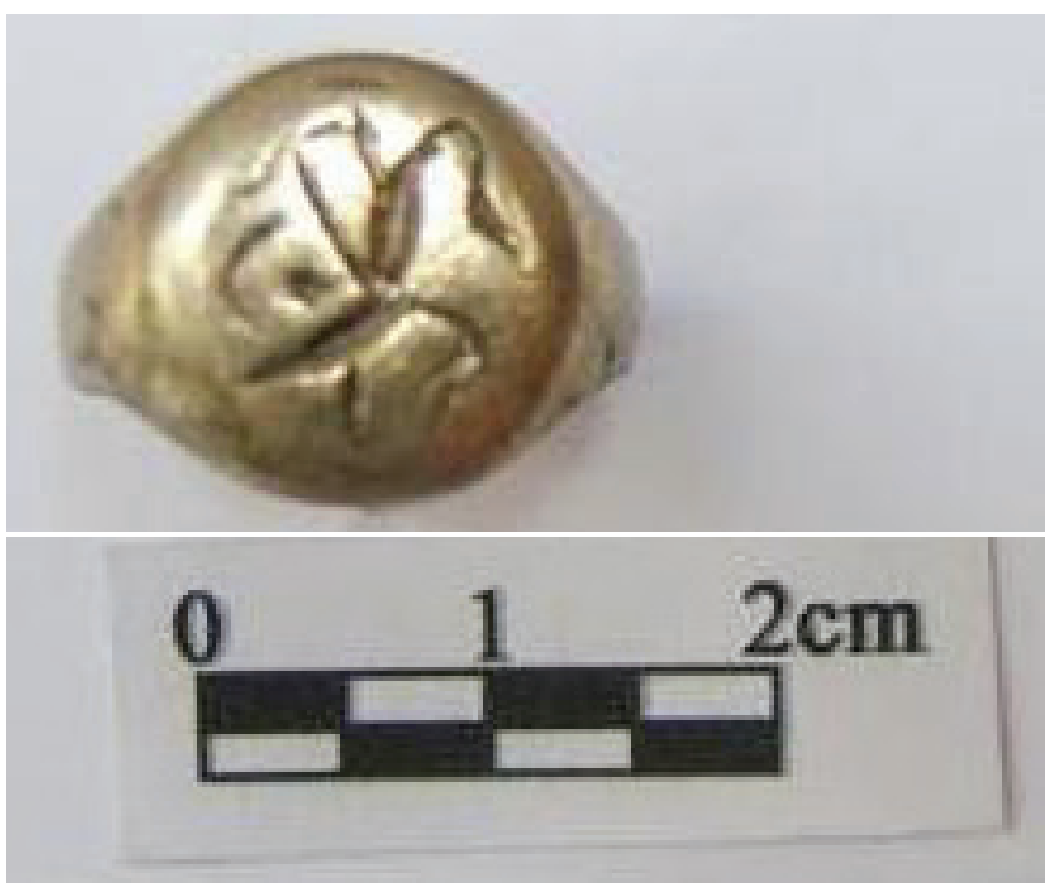

Fig 11.2 
Ege Üniversitesi, Edebiyat Fakültesi Sanat Tarihi Dergisi ISSN $1300-5707$ Cilt: 30, Sayı: 1 Nisan 2021
Ege University, Faculty of Letters Journal of Art History e-ISSN 2636-8064 Volume: 30, Issue: 1 April 2021

\section{İternet Sayfası (Aclk Erisim) | Internet Page (Open Access) \\ DergiPark \\ https://dergipark.org.tr/std}

Sanat Tarihi Dergisi hakemli, bilimsel bir dergidir; Nisan ve Ekim aylarında olmak üzere yılda iki kez yayınlanır.

Lournal of Art History is a peer-reviewed, scholarly, periodical journal published biannually, in April and October. 